\title{
牛車腎気丸料乾燥エキスの薬理学的研究： 実験的糖尿病に対する作用
}

\author{
庄司 政満, 佐藤 仁美, 平井 康晴, 小國 泰弘 \\ 杉本 智潮, 森下 信一, 伊藤 千尋 \\ 救心製薬 (株) 総合研究所* \\ (1991年11月25日〔特])
}

\begin{abstract}
要約 : 牛車腎気丸料乾燥エキス (KJE) のサイプロヘプタジン (CPH) 誘発糖尿病モデル, アルドース レダクターゼ活性および坐骨神経圧挫による末梢性神経障害に対する作用を薬理学的に検討した. また KJE の作用を八味地黄丸の乾燥エキス（HJE）の作用と比較した. その結果, CPHによる耐糖能の低 下を KJE は $417 \mathrm{mg} / \mathrm{kg} / \mathrm{day}$ ( 1 日処方量の 5 倍量) で，また HJE は $367 \mathrm{mg} / \mathrm{kg} / \mathrm{day}$ ( 1 日処方量 の 5 倍量) で有意に抑制した. KJE および HJE はアルドースレダクターゼ活性を, 基質として DLglyceraldehyde を使用した場合，それぞれ IC50 $2.68 \times 10^{-5} \mathrm{~g} / \mathrm{ml}$ および $4.45 \times 10^{-5} \mathrm{~g} / \mathrm{ml}$ で，また， D-グルコースを使用した場合, それぞれ IC50 $1.04 \times 10^{-4} \mathrm{~g} / \mathrm{ml}$ および $1.55 \times 10^{-4} \mathrm{~g} / \mathrm{ml}$ で阻害した. 坐骨神経圧挫による神経障害を KJE は $209 \mathrm{mg} / \mathrm{kg} / \mathrm{day}$ （1 日処方量の2.5倍量）から, また HJE は $367 \mathrm{mg} / \mathrm{kg} / \mathrm{day}$ で有意に軽隇させた. KJE のこれらの作用は, 1 日処方量を基準として比較した場合, HJE の作用より強力であった.
\end{abstract}

\section{緒言 言}

救心漢方金匱腎気丸料ェキス顆粒は, ジオウ，サン シュユ, サンヤク, タクシャ, ブクリョウ，ボタンピ, ゴシッ, シャゼンシ, ケイヒ, 加工ブシ末からなる牛車 腎気丸料乾燥エキス (KJE) をのみやすい顆粒とした漢 方製剂で, 下肢痛, 腰痛, しびれ, 老人のかすみ目, か ゆみ, 排尿困難, 頻尿, むくみなどに効能を有するとさ れている. KJE は糖尿病性末梢神経障害1 6) や乏精子 症7,8) などに有効であることが報告されている.

近年, サイプロヘプタジン $(\mathrm{CPH})$ 投与により, 萃内 分泌機能を可逆的に抑制し, 糖尿病の臨床検査に护ける 耐糖能の低下状態をラットで作りだせることが報告9)さ れており, 生薬をはじめ作用の緩和な抗糖尿病薬の検索 に用いられている10). 我々は KJE の糖尿病に対する薬 理学的作用を明らかにする目的で, この $\mathrm{CPH}$ 誘発糖尿 病ラットに対する作用を検討した.

一方, 糖尿病の䍜病期間の長期化によって二次的に生 じる神経障害, 白内障, 腎症などの障害が問題になって

*\%166 東京都杉並区和田1-31-7
おり，その障害の発症機序としてポリオール代謝の活性 亢進が注目されている11, 12)。糖尿病によるポリオール 代謝の活性立進により, 膜透過性の極めて悪いソルビ トールやフルクトースが細胞内に蓄積して浸透圧が上昇 し，それが末梢神経の組織細胞内に蓄積した場合，神経 機能障害が生じるといわれている1314)。そこで，ポリ オール代謝の律速酵素であるアルドースレダクターゼ活 性に対する KJE の作用も検討した。

さらに, 発症してしまった神経障害に対する $\mathrm{KJE} の$ 作用を,ラットの坐骨神経を压挫して末梢神経障害を誘 発させ，障害からの回復を観察する系 ${ }^{15)}$ を用いて検討 した.

以上の実験において, KJE の作用強度と, 糖尿病の 治療に用いられ KJE と類似の処方を有する八味地黄丸 エキス (HJE) の作用強度とを比較した.

\section{実 験 方 法}

$\mathrm{CPH}$ 糖尿病モデルに対する作用および末梢性神経障 害に対する作用について，KJE および HJE の投与量は 以下のごとく 1 日処方量を基準に決定した. すなわち, $\mathrm{KJE}$ は 1 日処方量 $(5.0 \mathrm{~g} / 60 \mathrm{~kg} /$ day) の 2.5 (209 
$\mathrm{mg} / \mathrm{kg})$ または $5(417 \mathrm{mg} / \mathrm{kg})$ 倍量を, HJE は 1 日処 方量 $(4.4 \mathrm{~g} / 60 \mathrm{~kg} /$ day $)$ の $2.5(184 \mathrm{mg} / \mathrm{kg})$ または 5 $(367 \mathrm{mg} / \mathrm{kg})$ 倍量を, それぞれ $0.25 \% \mathrm{CMC}$ 水溶液に 懸濁して $10 \mathrm{ml} / \mathrm{kg}$ の容量で経口投与した。また，対照 群および正常対照群の動物には $0.25 \% \mathrm{CMC}$ 水溶液 10 $\mathrm{ml} / \mathrm{kg}$ を経口投与した.

\section{1. 実験材料}

\section{1）実験動物}

雄性の Wistar 系ラットあるいは SD 系ラット（共に 静岡実験動物農協）を使用した。

2) 使用薬物

牛車腎気丸料乾燥エキス (アルプス薬品工業) は漢方 処方「牛車腎気丸料」に従い, ジオウ $5.0 \mathrm{~g}$, サンシュユ $3.0 \mathrm{~g}$, サンヤク $3.0 \mathrm{~g}$, タクシャ $3.0 \mathrm{~g}$, ブクリョウ $3.0 \mathrm{~g}$, ボタンピ $3.0 \mathrm{~g}$, ゴシッ $3.0 \mathrm{~g}$, シャゼンシ 3.0 $\mathrm{g}$, ケイヒ $1.0 \mathrm{~g}$ および加工ブシ末 $1.0 \mathrm{~g}$ からなる生薬 の混合物を第十二改正日本薬局方 (日局) 飞記載されて いる常水を用いて $95 \sim 100^{\circ} \mathrm{C}$ で抽出し，その抽出液を日 局の製剤総則，エキス剤の製法に準拠して得た乾燥エキ スである. KJE $1 \mathrm{~g}$ は牛車腎気丸処方の原生薬の混合物 $5.6 \mathrm{~g}$ に相当し, 1 日処方量は $5.0 \mathrm{~g}$ である.八味地黄 丸料乾燥エキス (アルプス薬品工業) は漢方処方「八味 地黄丸料」に従い, ジオウ $5.0 \mathrm{~g}$, サンシュユ $3.0 \mathrm{~g}$, サンヤク $3.0 \mathrm{~g}$, タクシャ $3.0 \mathrm{~g}$, ブクリョウ $3.0 \mathrm{~g}$, ボ タンピ $3.0 \mathrm{~g}$, ケイヒ $1.0 \mathrm{~g}$ 扰よび加工ブシ末 $1.0 \mathrm{~g}$ か

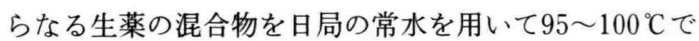
抽出し，その抽出液を日局の製剤総則，エキス剤の製法 に準拠して得た乾燥エキスである. HJE $1 \mathrm{~g}$ は八味地黄 丸処方の原生薬の混合物 $5.0 \mathrm{~g}$ に相当し, 1 日処方量は $4.4 \mathrm{~g}$ である.

その他， $\mathrm{CPH}$ (ペリアアクチン ${ }^{\circledR}$ 日本メルク万有), sodium carboxymethyl cellulose (国産化学, CMC), Dグルコース, 硫酸アンモニウム (和光純薬), DLglyceraldehyde (ナカライテスク), nicotinamideadenine dinucleotide phosphate reduced form $(オ リ エ$

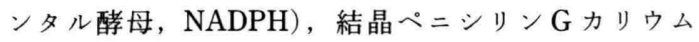
(萬有), スリンダク (クリノリル®錠 100 , 萬有), cyanocobalamin (Sigma, VB $\mathrm{VB}_{12}$ )を使用した.

\section{CPH 誘発糖尿病モデルに対する作用}

ラット（SD 系，実験開始時体重 $113 \sim 145 \mathrm{~g}$ )を使用 した. 被験薬投与開始前日に絶食したラットの血糖を杉 浦と平野16) の方法に準拠して測定した，その血糖值と 採血当日のラットの体重により群分けした.

実験的糖尿病モデルの作製拈よび経口糖負荷試験は,
後藤ら 10) の方法に準拠した. すなわち， 5 週齢のラット に被験薬を午前中に 1 回 35 日間経口投与し, 被験薬投与 開始 1 週間後から, 蒸留水に懸濁して調製した CPH 45 $\mathrm{mg} / \mathrm{kg}$ を $11 \mathrm{ml} / \mathrm{kg}$ の容量で, 午後に 1 回 28 日間経口投 与した。なお, 正常対照群には $\mathrm{CPH}$ のかわりに, 11 $\mathrm{ml} / \mathrm{kg}$ の蒸留水を経口投与した. $\mathrm{CPH}$ 投与開始後 2 お よび 4 週間目に, $40 \%$ グルコース溶液を $4.0 \mathrm{~g} / \mathrm{kg}$ の割 合で経口投与し，グルュース投与前 ( 0 分)，投与60分お よび120分後の血糖值を測定し，糖負荷試験を行った. ラットは採血前日, $16: 00$ 頃から絶食させた.

\section{3. アルドースレダクターゼに対する作用}

KJE および HJE 5 \% 5 メノールにて最終メタ ノール濃度 $0.17 \%$ となるよ5に懸濁後, 冷暗所にて 2 時 間放置し，超音波処理した後 $3000 \mathrm{rpm}, 15$ 分間， $4{ }^{\circ} \mathrm{C}$ で 遠心分離して, その上清を $0.45 \mu \mathrm{m}$ のミリポアフィル ターに通して使用した。 また，陽性対照薬として用いた スリンダクは $50 \%$ エタノールを含むリン酸緩衝液に溶解 し使用した.

アルドースレダクターゼ分画は Hayman and Kinoshita ${ }^{17)}$ の方法に準拠して採取した. すなわち，新 鮮な牛眼レンズを 3 倍量の冷蒸留水でホモジナイズし, $10000 \times \mathrm{g}$ で15分間, $3^{\circ} \mathrm{C} て ゙$ 遠心分離して上清を採取した. この上清に硫酸アンモニウムを順次 $40 \% ， 50 \% ， 75 \%$ 飽和になるよらに加えて，15分間の䚌拌と遠心分離によ り，その都度上清を得た． $75 \%$ 飽和で得られた沈渣を少

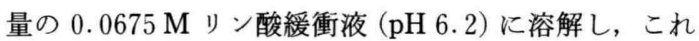
をアルドースレダクターゼ分画とした.

アルドースレダクターゼ活性は Terashima ら ${ }^{18)}$ の方 法に準拠して測定した. すなわち、スターラーの入った セル中に, 最終濃度 $0.073 \mathrm{mM}$ の NADPH, $0.3 \mathrm{M}$ の硫 酸アンモニウム， 4〜 $5 \mathrm{U}$ に相当するアルドースレダク ターゼ分画, 被験薬夜を入れ, これに $0.0675 \mathrm{M}$ リン

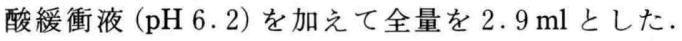
このセル中に基質として最終濃度 $1 \mathrm{mM}$ の DL-

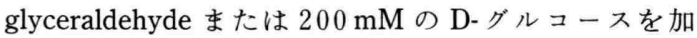
克, その後 5 分間の吸光度変化を $340 \mathrm{~nm}, 25^{\circ} \mathrm{C}$ にてダ ブルビーム分光光度計 (220A, 日立) で測定した. 対照 セルには基質以外の試薬溶液をすべて加えた．対照群で は被験薬のかわりに調製溶媒を加兄, 被験薬群と同様に 処理した. 各被験薬のアルドースレダクターゼ阻害率を 下式に従って算出し, IC50 を求めた.

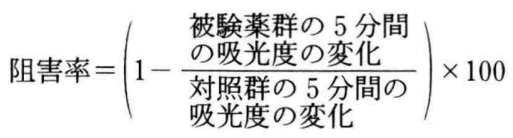




\section{4. 末梢性神経障害に対する作用}

ラット（Wistar 系，実験開始時体重 180～220 g) を 使用した. 長谷川ら ${ }^{15)}$ の方法に準拠して, 左側の坐骨 神経を脛骨神経と腓骨神経の分岐部より約 $5 \mathrm{~mm}$ 中枢 部に拈いて，接触面を平滑にしたペアン鉗子で 3 分間一 定圧 (鉗子三段目) で圧挫した. 圧挫後直ちに縫合し, 結晶ペニシリン $\mathrm{G}$ カリウムを 3 万単位筋肉内に注入し た.な打擬手術は神経露出のみとした。

$\mathrm{KJE}$ および HJE は圧挫当日より毎日経口投与した. また, 陽性対照薬として $\mathrm{VB}_{12}$ を使用し， $1 \mathrm{mg} / \mathrm{kg}$ を 1 $\mathrm{ml} / \mathrm{kg}$ の容量で圧挫当日より毎日腹腔内投与した. 圧 挫後, 末梢神経麻痺の程度を長谷川ら 15) の採点基準に 従い, 歩行時の障害の程度に応じた以下に示す 10 段階の スコアーにて採点した.

\section{歩行障害スコアー}

$-9:$ 圧挫側の後肢の背面を床に密着し, 後ろへ投げ出 したままでいる，歩行時も後肢を引きずり，体の下 に引っ込めることはない.

-8 : 後肢を体の下に引っ込めているが, 前述の行動も しばしばみられる。

-7 : 後肢の背面全体あるいは指の背面を床に接触させ て, 後肢を後ろに投げ出したまま歩くことが 3 分間 に 1,2 度ある.

-6 : 上述の行動が全くみられない. 後肢のそれぞれの 指は互に閉じて接触している. 指自体は下垂し, 弯 曲している．また外反（後肢の外側縁をあげる）あ るいは内反（後肢の内側縁をあげる）していること が多い. 歩行時は, かかとをあげない. 後肢が横や 斜め後ろに残ったり, 指の背面を引きずって歩くこ とがある.

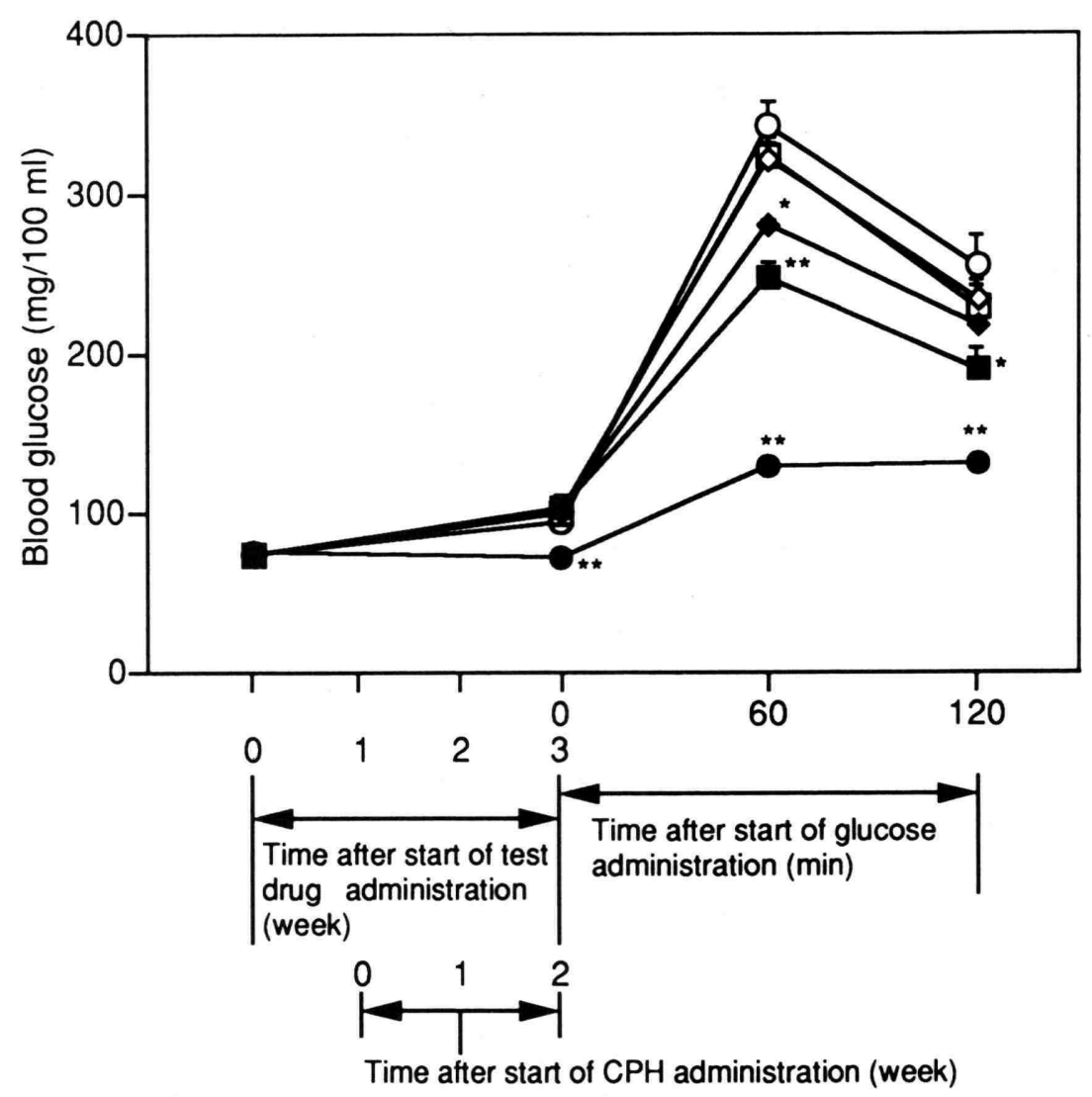

Fig. 1 Effects of KJE and HJE on the glucose tolerance after the glucose loading in CPH-treated (2 weeks) rats. The data are expressed as means \pm S.E. $(\mathrm{n}=10){ }^{*}: \mathrm{P}<0.05,{ }^{* *}: \mathrm{P}<0.01$, significant differences from

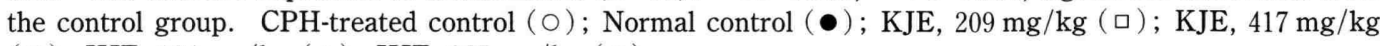
(•); HJE, $184 \mathrm{mg} / \mathrm{kg}(\diamond)$; HJE, $367 \mathrm{mg} / \mathrm{kg}(\bullet)$. 


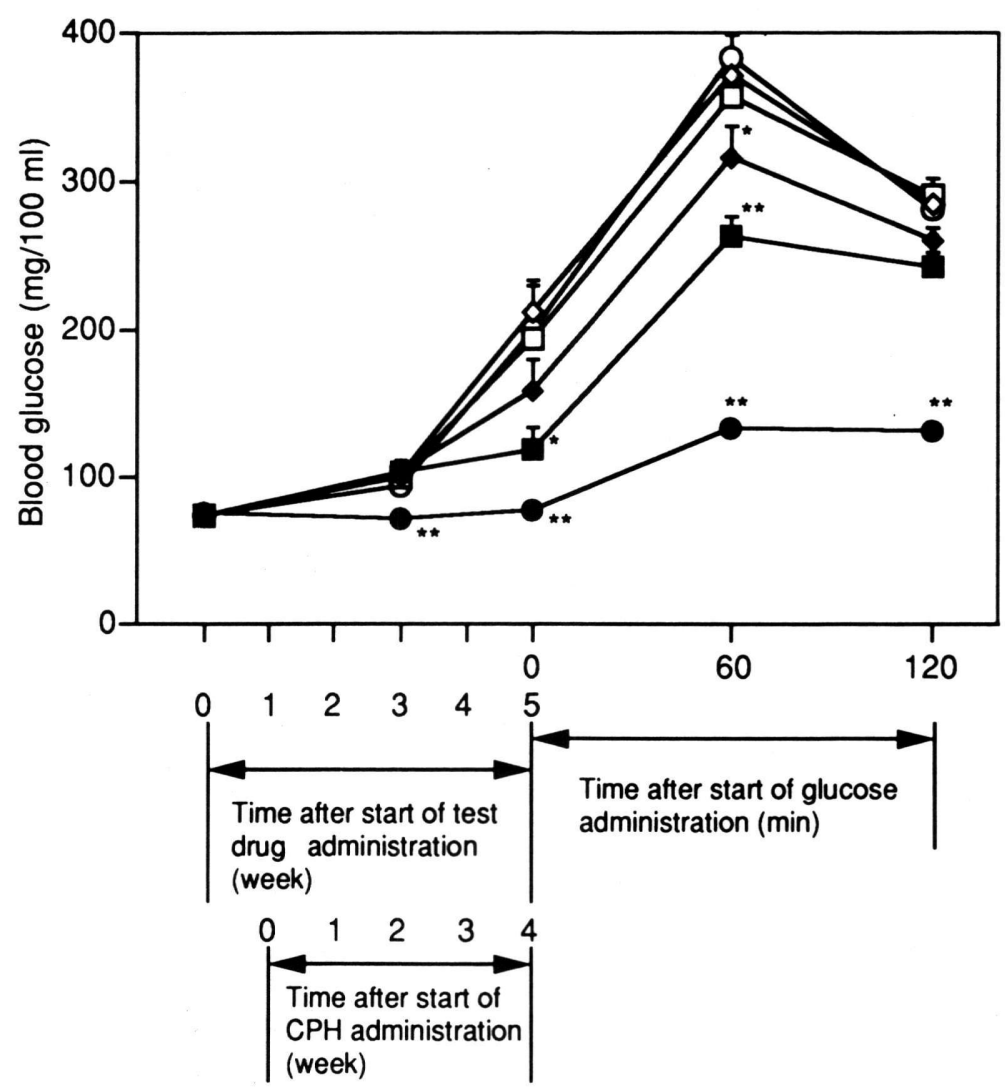

Fig. 2 Effects of $\mathrm{KJE}$ and HJE on the glucose tolerance after the glucose loading in CPH-treated (4 weeks) rats. Symbols and explanations are the same as those in the legend to Fig. 1.

-5 : 第一指あるいは第五指の先端が見え始める. しか し外反あるいは内反し，第一指や第五指が見えない 時もある.かかとはあげない. 足底も床につけない。 -4 : 第一指と第五指が明らかに見学る. しかし外反や 内反も時々する. 足底は床に密着することなく, 浮 かしている，歩行時には，かかとをあげず，足全体 を運ぶ.

-3 : 指は明らかに開いている. 足底は床から浮かして いることもあるが，つける時もある．かかとをあげ て歩くこともある. だが, 足指の背屈はまだ不可能 で，しっかり体をささえて歩くことは少ない，対照 側に比し，かかとのあげ方が低い。

-2 : 歩行時にかかとを対照側と同じ位あげる. 足指の 背屈が可能となり, しっかり体をささえて歩く.し かし対照側に比し, 不安定だったり, わずか指が弯 曲していたりする.
-1 : 動物をさわらない場合では, 対照側と区別がつか ない、けれども，動物をつかんで持ちあげる時に， 指が弯曲したり, 対照側に比し異常がわずか認めら れる。

0 : 正常

さらに，坐骨神経の圧挫により，正常では大きく開い ている指を閉じ互いに密着するようになるため ${ }^{15)}$, 第一, 第五指間距離および第二, 第四指間距離も麻瘏の指標と して測定した。指間距離の変化は右側後肢の指間距離を 100\%とした時の圧挫側の指間距離の比で表した.さら に，神経圧挫と薬物投与の筋湿重量に対する影響を，圧 挫後14日目に左右の腓腹筋, ヒラメ筋, 足底筋および前 脛骨筋を摘出し，右側の筋湿重量を $100 \%$ とした時の圧 挫側の筋湿重量比から求めた.

\section{5. 統計処理}

末梢性神経障害に拈ける歩行障害の程度を表すスコ アー以外の実験結果は多重比較検定により解析した。す 


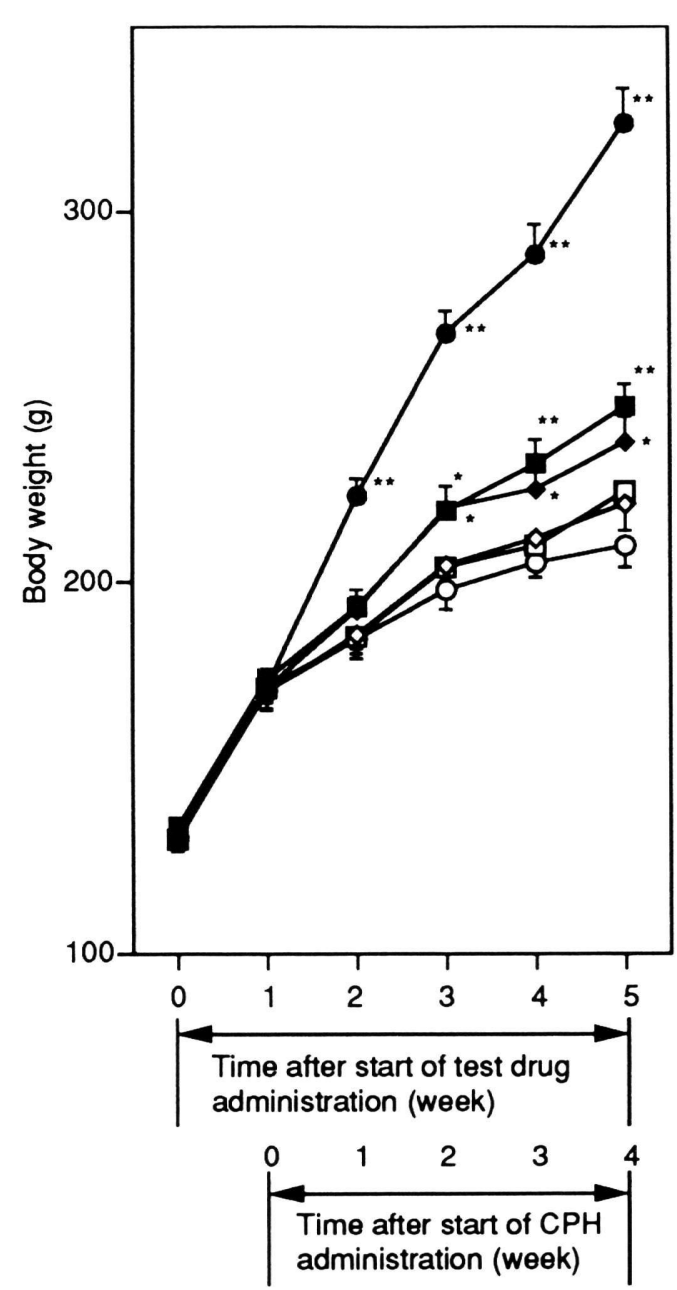

Fig. 3 Body weight of rats administered, KJE or $\mathrm{HJE}$, and CPH. Symbols and explanations are the same as those in the legend to Fig. 1.
なわち, Bartlett の検定を行い，等分散している場合は， 一元配置分散分析を行った. 一元配置分散分析の結果, 平均值に有意差を認めた場合，Duncan 法で検定した。 また，Bartlettの検定の結果，等分散していないと判定 された場合は，Kruskal-Wallis の検定を行い，群間に有 意差が認められた場合, Williams の Wilcoxon 型検定 を行った。末梢性神経障害において得られたスコアーは $U$ 検定によって解析した.

\section{実 験 結 果}

\section{1. $\mathrm{CPH}$ 誘発糖尿病モデルに対する作用}

$\mathrm{CPH}$ 投与 2 週間後, 糖負荷試験直前の血糖值は, 正 常対照群に比べて $\mathrm{CPH}$ 投与群で有意に上昇し, $\mathrm{CPH}$ 投与 4 週間後ではその傾向はさらに顕著となった. $\mathrm{KJE}$ は $417 \mathrm{mg} / \mathrm{kg} /$ day 投与によりこの血糖値の上昇を, $\mathrm{CPH}$ 投与 4 週間目で有意に抑制した（図 1，2）.

糖負荷後の血糖值は $\mathrm{CPH}$ 投与 2 および 4 週間後正常 対照群に比べて有意に上昇し， $\mathrm{CPH}$ による耐糖能の低 下が示された。 KJEおよび $\mathrm{HJE}$ は各々 $417 \mathrm{mg} / \mathrm{kg} /$ day, $367 \mathrm{mg} / \mathrm{kg} /$ day 投与により, CPH 投与後 2 および 4 週間に拈いて, 糖負荷 60 分後に対照群に比べて有意に 耐糖能の低下を改善した。また，KJEは $417 \mathrm{mg} / \mathrm{kg} /$ day 投与により, CPH 投与後 2 週間における糖負荷 120 分後でも，耐糖能の低下を有意に改善させた（図 1，2）.

$\mathrm{CPH}$ 投与 1 週間後, $\mathrm{CPH}$ 投与群では正常対照群に比 べて体重の増加が抑制された. $\mathrm{CPH}$ 投与 2 週間以後, $\mathrm{KJE}$ および $\mathrm{HJE}$ は各々 $417 \mathrm{mg} / \mathrm{kg} / \mathrm{day}, 367 \mathrm{mg} / \mathrm{kg} /$ day 投与により，体重の増加の抑制を有意に改善した (図 3 ).

Table 1 Effects of KJE, HJE and sulindac on aldose reductase activities with $1 \mathrm{mM}$ DL-glyceraldehyde as the substrate in homogenates of bovine lens

\begin{tabular}{lccc}
\hline Drugs & $\begin{array}{c}\text { Concentration } \\
(\mathrm{g} / \mathrm{ml})\end{array}$ & $\begin{array}{c}\text { Inhibition } \\
(\%)\end{array}$ & $\begin{array}{c}\text { IC50 }(\mathrm{g} / \mathrm{ml}) \\
(95 \% \text { confidence limits })\end{array}$ \\
\hline KJE & $1 \times 10^{-5}$ & $26.5 \pm 5.0$ & \\
& $3 \times 10^{-5}$ & $50.5 \pm 4.4$ & $2.68 \times 10^{-5}$ \\
& $1 \times 10^{-4}$ & $80.6 \pm 5.7$ & $\left(1.91 \times 10^{-5}-3.62 \times 10^{-5}\right)$ \\
HJE & $1 \times 10^{-5}$ & $15.6 \pm 3.5$ & $4.45 \times 10^{-5}$ \\
& $3 \times 10^{-5}$ & $42.9 \pm 4.1$ & \\
& $1 \times 10^{-4}$ & $69.0 \pm 3.7$ & $\left(3.69 \times 10^{-5}-5.59 \times 10^{-5}\right)$ \\
Sulindac & $1 \times 10^{-7}(\mathrm{M})$ & $34.8 \pm 3.4$ & $2.59 \times 10^{-7}(\mathrm{M})$ \\
& $1 \times 10^{-6}(\mathrm{M})$ & $57.9 \pm 2.8$ & $\left(1.28 \times 10^{-7}-5.03 \times 10^{-7} \mathrm{M}\right)$ \\
\hline
\end{tabular}

The data are expressed as means \pm S. E. $(n=5)$. 
Table 2 Effects of KJE, HJE and sulindac on aldose reductase activities with $200 \mathrm{mM}$ D-glucose as the substrate in homogenates of bovine lens

\begin{tabular}{lccc}
\hline Drugs & $\begin{array}{c}\text { Concentration } \\
(\mathrm{g} / \mathrm{ml})\end{array}$ & $\begin{array}{c}\text { Inhibition } \\
(\%)\end{array}$ & $\begin{array}{c}\text { IC50 }(\mathrm{g} / \mathrm{ml}) \\
(95 \% \text { confidence limits })\end{array}$ \\
\hline KJE & $3 \times 10^{-5}$ & $23.6 \pm 2.0$ & \\
& $1 \times 10^{-4}$ & $47.7 \pm 2.1$ & $1.04 \times 10^{-4}$ \\
& $3 \times 10^{-4}$ & $74.0 \pm 1.3$ & $\left(9.32 \times 10^{-5}-1.17 \times 10^{-4}\right)$ \\
HJE & $3 \times 10^{-5}$ & $14.6 \pm 3.1$ & $1.55 \times 10^{-4}$ \\
& $1 \times 10^{-4}$ & $36.5 \pm 2.6$ & \\
& $3 \times 10^{-4}$ & $68.2 \pm 2.5$ & $\left(1.36 \times 10^{-4}-1.82 \times 10^{-4}\right)$ \\
Sulindac & $1 \times 10^{-8}(\mathrm{M})$ & $22.6 \pm 2.7$ & $1.70 \times 10^{-8}(\mathrm{M})$ \\
& $1 \times 10^{-7}(\mathrm{M})$ & $43.8 \pm 3.0$ & \\
& $1 \times 10^{-6}(\mathrm{M})$ & $86.0 \pm 5.0$ & $\left(3.59 \times 10^{-10}-1.72 \times 10^{-8} \mathrm{M}\right)$ \\
\hline
\end{tabular}

The data are expressed as means \pm S. E. $(n=5)$.

Table 3 Effects of $\mathrm{KJE}, \mathrm{HJE}$ and $\mathrm{VB}_{12}$ on the distance between the 1st and 5 th digits of rat hind-paw after crushing at a distal level of the sciatic nerve

\begin{tabular}{|c|c|c|c|c|c|c|c|}
\hline \multirow{3}{*}{ Drugs } & \multirow{3}{*}{$\begin{array}{c}\text { Dose } \\
\text { (mg/kg/day) }\end{array}$} & \multirow{3}{*}{ Route N } & \multicolumn{5}{|c|}{ Changes $(\%)$} \\
\hline & & & \multicolumn{5}{|c|}{ Days after first administration } \\
\hline & & & 0 & 2 & 4 & 7 & 14 \\
\hline \multicolumn{2}{|l|}{$\begin{array}{l}\text { Crushed } \\
\text { control }\end{array}$} & p.o. 9 & $104.9 \pm 1.7$ & $48.4 \pm 2.5$ & $45.8 \pm 0.9$ & $49.5 \pm 1.8$ & $45.5 \pm 2.3$ \\
\hline \multicolumn{2}{|l|}{$\begin{array}{l}\text { Sham } \\
\text { operation }\end{array}$} & p.o. 10 & $104.5 \pm 1.6$ & $96.9 \pm 2.4^{* *}$ & $95.5 \pm 1.2^{* *}$ & $102.4 \pm 1.3^{* *}$ & $95.2 \pm 1.4^{* *}$ \\
\hline \multirow[t]{2}{*}{$\mathrm{KJE}$} & 209 & p.o. 10 & $107.2 \pm 2.7$ & $52.4 \pm 3.3$ & $48.0 \pm 1.2$ & $54.1 \pm 1.8$ & $58.2 \pm 3.2^{* *}$ \\
\hline & 417 & p.o. 10 & $107.5 \pm 1.9$ & $54.9 \pm 2.4$ & $50.6 \pm 1.2^{*}$ & $52.9 \pm 2.7$ & $62.9 \pm 1.8^{* *}$ \\
\hline $\mathrm{HJE}$ & 367 & p.o. 9 & $106.4 \pm 2.8$ & $54.8 \pm 3.6$ & $44.7 \pm 1.6$ & $45.3 \pm 2.9$ & $54.6 \pm 2.7^{*}$ \\
\hline $\mathrm{VB}_{12}$ & 1 & i.p. 10 & $107.4 \pm 3.3$ & $53.4 \pm 1.9$ & $47.0 \pm 1.3$ & $49.2 \pm 2.3$ & $62.9 \pm 2.6^{* *}$ \\
\hline
\end{tabular}

The data are expressed as the percentage of distances between the 1 st and 5 th digits of the left hind-paw relative to the right hind-paw. ${ }^{*}: \mathrm{P}<0.05,{ }^{* *}: \mathrm{P}<0.01$, significant differences from the control group.

Table 4 Effects of KJE, HJE and $\mathrm{VB}_{12}$ on behavior of the left hind-paw after crushing at a distal level of the rat sciatic nerve

\begin{tabular}{|c|c|c|c|c|c|c|c|c|c|c|}
\hline \multirow{3}{*}{ Drugs } & \multirow{3}{*}{$\begin{array}{l}\text { Dose } \\
\left(\begin{array}{l}\mathrm{mg} / \\
\mathrm{kg} / \\
\text { day }\end{array}\right)\end{array}$} & \multirow{3}{*}{\multicolumn{2}{|c|}{ Route N }} & \multicolumn{7}{|c|}{ Score } \\
\hline & & & & \multicolumn{7}{|c|}{ Days after first administration } \\
\hline & & & & 0 & 1 & 2 & 4 & 7 & 10 & 14 \\
\hline \multicolumn{2}{|c|}{$\begin{array}{r}\text { Crushed } \\
\text { control }\end{array}$} & p.o. & 9 & $0.0 \pm 0.0$ & $-7.0 \pm 0.0$ & $-6.6 \pm 0.2$ & $-6.4 \pm 0.2$ & $-6.1 \pm 0.1$ & $-5.7 \pm 0.2$ & $-5.4 \pm 0.2$ \\
\hline \multicolumn{2}{|c|}{$\begin{array}{l}\text { Sham } \\
\text { operation }\end{array}$} & p.o. & 10 & $0.0 \pm 0.0$ & $0.0 \pm 0.0^{* *}$ & $0.0 \pm 0.0^{* *}$ & $0.0 \pm 0.0^{* *}$ & $0.0 \pm 0.0^{* *}$ & $0.0 \pm 0.0^{* *}$ & $0.0 \pm 0.0^{* *}$ \\
\hline \multirow[t]{2}{*}{$\mathrm{KJE}$} & 209 & p.o. & 10 & $0.0 \pm 0.0$ & $-7.0 \pm 0.0$ & $-6.0 \pm 0.0^{*}$ & $-6.1 \pm 0.1$ & $-6.0 \pm 0.0$ & $-5.2 \pm 0.2$ & $-4.4 \pm 0.3^{* *}$ \\
\hline & 417 & p.o. & 10 & $0.0 \pm 0.0$ & $-7.1 \pm 0.1$ & $-6.2 \pm 0.1$ & $-6.0 \pm 0.0$ & $-6.0 \pm 0.0$ & $-4.7 \pm 0.2^{* *}$ & $-4.2 \pm 0.2^{* *}$ \\
\hline HJE & 367 & p.o. & 9 & $0.0 \pm 0.0$ & $-7.0 \pm 0.0$ & $-6.2 \pm 0.1$ & $-6.1 \pm 0.1$ & $-6.0 \pm 0.0$ & $-5.1 \pm 0.1$ & $-4.7 \pm 0.2^{* *}$ \\
\hline $\mathrm{VB}_{12}$ & 1 & i.p. & 10 & $0.0 \pm 0.0$ & $-7.0 \pm 0.0$ & $-6.0 \pm 0.0^{*}$ & $-6.0 \pm 0.0$ & $-6.0 \pm 0.0$ & $-4.7 \pm 0.2^{* *}$ & $-4.2 \pm 0.2^{* *}$ \\
\hline
\end{tabular}

The data are expressed as the score on a scale of $10(-9 \sim 0)$ according to the degree of behavioral disorder of the left hind-paw. ${ }^{*}: \mathrm{P}<0.05,{ }^{* *}: \mathrm{P}<0.01$, as compared with the control group using the $U$-test. 
A

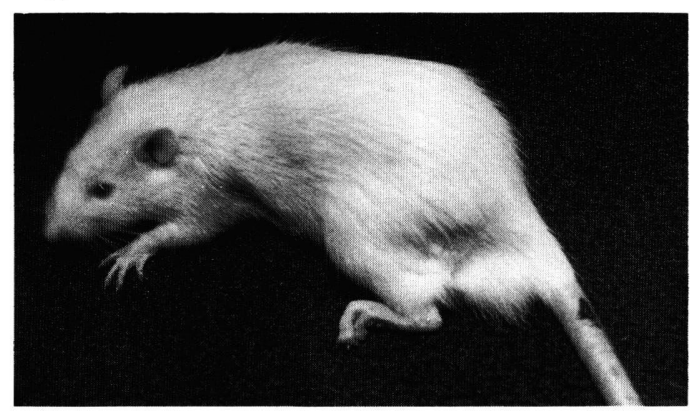

B

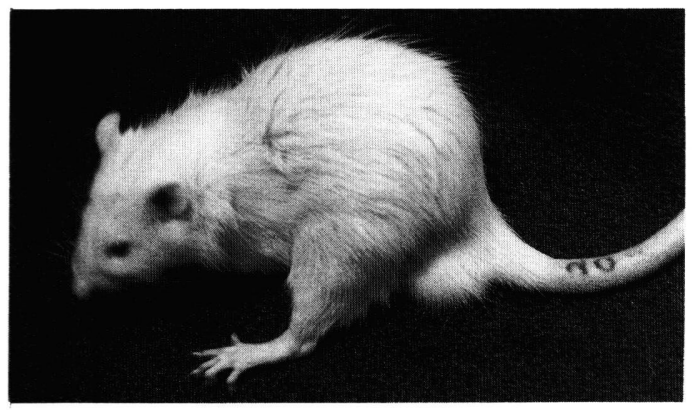

Photo. 1 Rats at 14 days after crushing at a distal level of the sciatic nerve. A: A rat of the control group. B: A rat administered $\mathrm{KJE}$ at $417 \mathrm{mg} / \mathrm{kg}$ for 14 days.

Table 5 Effects of KJE, $\mathrm{HJE}$ and $\mathrm{VB}_{12}$ on muscle atrophy of the rat hind limb 14 days after crushing at a distal level of the sciatic nerve

\begin{tabular}{|c|c|c|c|c|c|c|c|}
\hline \multirow{2}{*}{ Drugs } & \multirow{2}{*}{$\begin{array}{c}\text { Dose } \\
(\mathrm{mg} / \mathrm{kg} / \text { day })\end{array}$} & \multirow{2}{*}{ Route } & \multirow{2}{*}{$\mathrm{N}$} & \multicolumn{4}{|c|}{ Changes $(\%)$} \\
\hline & & & & G & $\mathrm{S}$ & $\mathrm{TA}$ & $\mathrm{P}$ \\
\hline \multicolumn{2}{|c|}{ Crushed control } & p.o. & 9 & $46.0 \pm 0.8$ & $55.2 \pm 1.5$ & $38.5 \pm 3.3$ & $43.7 \pm 2.3$ \\
\hline \multicolumn{2}{|c|}{ Sham operation } & p.o. & 10 & $99.3 \pm 0.9^{* *}$ & $100.9 \pm 2.2^{* *}$ & $98.6 \pm 2.1^{* *}$ & $91.1 \pm 2.2^{* *}$ \\
\hline \multirow[t]{2}{*}{$\mathrm{KJE}$} & 209 & p.o. & 10 & $52.4 \pm 0.9^{* *}$ & $64.7 \pm 1.4^{* *}$ & $47.5 \pm 1.6$ & $49.1 \pm 1.7$ \\
\hline & 417 & p.o. & 10 & $57.1 \pm 1.3^{* *}$ & $65.8 \pm 2.0^{* *}$ & $55.5 \pm 2.4^{* *}$ & $54.9 \pm 2.8^{* *}$ \\
\hline HJE & 367 & p.o. & 9 & $50.4 \pm 1.2^{*}$ & $58.9 \pm 1.2$ & $45.4 \pm 1.0$ & $49.7 \pm 2.3$ \\
\hline $\mathrm{VB}_{12}$ & 1 & i.p. & 10 & $53.4 \pm 1.8^{* *}$ & $62.6 \pm 3.3^{* *}$ & $50.5 \pm 2.5^{*}$ & $53.5 \pm 2.3$ \\
\hline
\end{tabular}

The data are expressed as the percentage of muscle weight of the left hind-paw relative to the right hind-paw. ${ }^{*}: \mathrm{P}<0.05,{ }^{* *}: \mathrm{P}<0.01$, significant differences from the control group. G: gastrocnemius muscle, $\mathrm{S}$ : soleus muscle, TA: tibialis anterior muscle, $\mathrm{P}$ : plantaris muscle.

\section{2. アルドースレダクターゼに対する作用}

KJE は基質とし DL-glyceraldehydeを使用した場合 も，また D-グルュースを使用した場合もアルドースレ ダクターゼ活性を阻害し, IC50 は各々 $2.68 \times 10^{-5}$ $\mathrm{g} / \mathrm{ml}, 1.04 \times 10^{-4} \mathrm{~g} / \mathrm{ml}$ であった. $\mathrm{HJE}$ も, KJE と同様 に，基質として DL-glyceraldehyde を使用した場合も， また D-グルコースを使用した場合もアルドースレダク ターゼ活性を阻害し, IC50 は各々 $4.45 \times 10^{-5} \mathrm{~g} / \mathrm{ml}$, $1.55 \times 10^{-4} \mathrm{~g} / \mathrm{ml}$ であった。本た，陽性対照薬であるス リンダクも同様にアルドースレダクターゼ活性を阻害 し，基質として DL-glyceraldehydeを使用した場合 IC 50 は $2.59 \times 10^{-7} \mathrm{M}$ であり，D-グルコースを使用した場 合 IC50 は $1.70 \times 10^{-8} \mathrm{M}$ であった（表 1，2）。

\section{3. 末梢性神経障害に対する作用}

$\mathrm{KJE}$ は2 $09 \mathrm{mg} / \mathrm{kg} /$ day から，また HJEは 367 $\mathrm{mg} / \mathrm{kg} /$ day で, $\mathrm{VB}_{12}$ は $1 \mathrm{mg} / \mathrm{kg} /$ day で第一, 第五 (表 3 ) および第二, 第四指間距離の短縮を有意に抑制した. また, 歩行時の障害の程度も $\mathrm{KJE}$ は $209 \mathrm{mg} / \mathrm{kg} / \mathrm{day}$
からまた HJEは $367 \mathrm{mg} / \mathrm{kg} /$ day で, $\mathrm{VB}_{12}$ は $1 \mathrm{mg} /$ $\mathrm{kg} /$ day で有意に緩和した（表 4 ，写真 1 ).

また，KJE $417 \mathrm{mg} / \mathrm{kg} /$ day および $\mathrm{VB}_{12} 1 \mathrm{mg} / \mathrm{kg} /$ day 投与群は, 坐骨神経圧挫後 14 日目の, 左足腓腹筋, ヒラメ筋，足底筋，前脛骨筋すべての，HJE 367 $\mathrm{mg} / \mathrm{kg} /$ day 投与群は腓腹筋の, 湿重量の減少を有意に 抑制した．KJE は $209 \mathrm{mg} / \mathrm{kg} /$ day 投与群でも腓腹筋お よびヒラメ筋の湿重量の減少を有意に抑制した（表 5 ）.

\section{考察}

$\mathrm{CPH}$ による実験的糖尿病モデルを作製し, 被験薬の 糖尿病に対する作用を検討した。 $\mathrm{CPH}$ 誘発糖尿病の発 症メカニズムは $\mathrm{CPH}$ によるランゲルハンス島に拈ける 糖の感受性の部分的低下, あるいはランゲルハンス島で のインシュリン生合成の部分的低下によるものと報告さ れている ${ }^{9)}$ ここような原因による耐糖能の低下は糖尿 病にしばしば認められる. KJEおよび $\mathrm{HJE}$ は CPH に より低下した耐糖能を有意に改善したことから，KJE 
および HJE は糖尿病における耐糖能の低下を改善する ものと思われる. $\mathrm{CPH}$ 誘発糖尿病は糖負荷試験後のみ に血糖值が上昇して，耐糖能の低下が認められ，また膵 内分泌以外の障害を示さず, $\mathrm{CPH}$ 投与中止により糖負 荷時の血糖值も対照と同程度に回復することから緩和な モデルであると報告されている泉が，我々の結果では，

$\mathrm{CPH}$ の投与により糖負荷試験後のみならず糖負荷試験 前の血糖值も有意に上昇し, 大西らのモデルよりも症状 が強く発現しているよらに思われた，KJEはこの上昇 を有意に抑制した。山原ら ${ }^{19)}$ は八味丸に血糖上昇抑制 作用を認めており，八味丸構成生薬の 1 つであるサン シュュの含有成分のウルソール酸 $(500 \mathrm{mg} / \mathrm{kg}$, p.o.) に 活性があると報告しているが，ウルソール酸は脂溶性成 分であり，八味丸水製乾燥エキスでは血糖上昇に対する 抑制作用が認められないとも報告している。本実験にお。 いても，HJE は糖負荷以前の血糖上昇を抑制する傾向 を示したものの有意な作用は示さなかった。一方， KJE は耐糖能低下作用のみならず血糖上昇抑制作用を も有することが認められたが，これはHJEに含まれず KJE に含まれる生薬のゴシッおよびシャゼンシに血糖 上昇を抑制する成分が含まれている可能性を示唆するも のである、しかしながら, 現在のところ, 両生薬に血糖 上昇抑制成分が含まれているとの報告は得られていな い. また， $\mathrm{CPH}$ 投与によりその毒性と思われる体重増 加の抑制が認められた，KJE および HJE はこの体重増 加の抑制を改善し $\mathrm{CPH}$ の毒性を軽減あるいは $\mathrm{CPH}$ に よる糖尿病誘発過程に作用しているものと考えられた. この作用は糖代謝の改善に基づくものと思われた.

アルドースレダクターゼは糖尿病などの高血糖状態に おいて細胞膜を透過しにくいソルビトールやフルク トースの産生を元進し, 結果として糖尿病によって二次 的に生じる神経障害, 白内障, 腎症などの障害の発症に 関与しており，アルドースレダクターゼ活性を抑制する ことは,これら障害の発症を抑制しらるものと思われる. KJE および HJE がアルドースレダクターゼ活性阻害作 用を有することは，KJE および HJE に糖尿病によって 二次的に生じるこれらの障害を抑制する可能性がある.

KJE および HJE は耐糖能の改善とアルドースレダク ターゼ活性阻害作用により, 糖尿病性神経障害の改善と 予防に有効であると考えられる. 特に, KJE は糖尿病 性神経障害に対して有効であるという多くの臨床報 告1 6) がある.

$\mathrm{KJE}$ および HJE の作用を坐骨神経圧挫による神経障 害モデルによって検討したところ, 両薬物とも歩行障害,
麻痺，坐骨神経支配筋の萎縮の回復を促進した。本モデ ルは神経障害からの回復過程に対する薬物の効果を判定 する目的で利用されて括り， $\mathrm{VB}_{12}{ }^{15)}$, 牛黄人参製剂20) などによる障害からの回復促進が報告されている. $\mathrm{KJE}$ の末梢神経障害回復促進作用のメカニズムは不明 であるが，その配合生薬のケイヒ ${ }^{21) ， フ ゙ シ 22) ~ お よ ひ ゙ コ ゙ ~}$ シッ ${ }^{23)}$ に血管拡張作用が報告されていることから，末 梢の血流改善作用が関与している可能性も考えられる. 糖尿病性神経障害の病因に循環障害が関与して扣り ${ }^{24)}$, 血管拡張剤が糖尿病性神経障害に有効であるとの報告も ある25)ことからも，糖尿病性神経障害の改善には $\mathrm{KJE}$ 中の血管拡張作用を有する生薬が関与している可能性が 示唆される.

$\mathrm{KJE} 417 \mathrm{mg} / \mathrm{kg} /$ day 投与群の神経障害改善作用は $\mathrm{VB}_{12} 1 \mathrm{mg} / \mathrm{kg} /$ day 投与群の作用とほ浪同程度と思われ た. $\mathrm{KJE} と \mathrm{VB}_{12}$ の神経障害改善作用の程度を比較し てみると, KJE $417 \mathrm{mg} / \mathrm{kg}$ は 1 日処方量の 5 倍量であ り, $\mathrm{VB}_{12}$ の $1 \mathrm{mg} / \mathrm{kg}$ は30〜 50倍量であることから, $\mathrm{KJE}$ の神経障害改善作用は $\mathrm{VB}_{12}$ に比べて強いものと 考えられる.

今回行ったすべての実験に拈いて，KJEの作用は $\mathrm{HJE}$ の作用より強力であった，KJE抽 $\mathrm{HJE}$ の $\mathrm{CPH}$ 誘発糖尿病モデルに対する作用について, KJE お よび HJE が耐糖能試験の際にグルコースの吸収に影響 を与え, KJE と HJE の耐糖能に対する作用強度の差が グルコースの吸収の差による可能性も考えられた。ただ 今回の場合 KJE は HJE の処方に 2 つ生薬を加えた 製剤であり，両者が非常に類似した処方であること，

$\mathrm{KJE}$ が $\mathrm{HJE}$ より強く $\mathrm{CPH}$ による体重増加の抑制を改 善し $\mathrm{CPH}$ の毒性を軽減しており，糖代謝を改善してい る可能性が考えられることなどから, 両薬物の作用強度 の差がグルコースの吸収の差である可能性は少ないもの

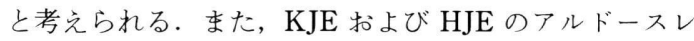
ダクターゼ阻害作用について，KJE および HJEのアル ドースレダクターゼ阻害強度の差がメタノール抽出効率 によって影響をらける可能性が考えられた。 しかしこれ についても KJE と HJE が非常に類似した処方である こと，また別法 ${ }^{26)} て ゙ も \mathrm{KJE}$ および $\mathrm{HJE}$ 製剤のアル ドースレダクターゼ阻害作用は前者の作用が強いと報告 されて拈り,我々の結果とも一致していることなどから， 両薬物の作用強度の差が抽出効率に影響をらけている可 能性は少ないものと考えられる.

以上のように, KJE は $\mathrm{HJE} よ り$ 強力な耐糖能改善, 血糖上昇抑制, アルドースレダクターゼ阻害, 神経障害 
からの回復促進作用を有することが明らかとなり，これ らの作用により糖尿病性神経障害を改善するものと考光 られた。

救心漢方金貴腎気丸料ェキス顆粒は，原料である $\mathrm{KJE}$ をのみやすい顆粒にした漢方製剂である. KJE が 糖尿病性神経障害を改善するものと考えられることか ら，その製剤である救心漢方金匱腎気丸料エキス顆粒も 同様の作用を有するものと予想され，KJE 同様，糖尿 病性神経障害に対しての有効性が期待される.

謝辞 : 本研究にあたり生薬エキスを提供いただいたアル プス薬品工業株式会社に深謝いたします。

\section{文献}

1）城石平一, 加藤弘已, 大角誠治, 矢野三郎：糖尿病 性神経障害に対する和漢薬治療の試久一桂枝加术附 湯, 八味地黄丸, 牛車腎気丸の使用経験. 和漢医薬 会誌 2, 144 145 (1985)

2）佐藤祐造, 他10名：糖尿病性神経障害に対する東洋 医学的治療 (第 2 報) 一牛車腎気丸とメコバラミン との比較一. 和漢医薬会誌 $2,580 \sim 581$ (1985)

3）鳥羽研二, 他11名 : 老年者糖尿病性神経障害の治療 に関する研究一牛車腎気丸の証の再検討一. 和漢医 薬会誌 3, 456〜457 (1986)

4) 谷内孝次, 槙村博之, 藤原啓子, 人位 晃, 郡 耕介, 泰井耕造, 松岡 瑛: 糖尿病性神経障害に対する牛 車腎気丸の臨床使用経験. 和漢医薬会誌 3, 458 459 (1986)

5）石垣健一，他11名：糖尿病性神経障害に対する牛車 腎気丸の有効性の検討. 診療と新薬 23, 2511〜2524 (1986)

6）佐藤祐造, 他 10 名 : 糖尿病性神経障害の東洋医学的 治療 (第 4 報) 一牛車腎気丸投与群の有効症例の背 景因子一．和漢医薬会誌 4, 316 317（1987）

7）太田博孝, 福島峰子 : 牛車腎気丸の乏精子症に対す る効果. 和漢医薬会誌 5, 490 491（1988）

8）五味淵秀人, 貝原 学, 太田昭彦: 牛車腎気丸の男 性不妊への効果. 基礎と臨床 25, 1601〜1603（1991）

9）大西栄子, 山田俊雄, 山田和雄, 井上 肇, 瀬山 義幸, 山下三郎：ストレプトゾトシンおよびサイプ ロヘプタジンによる実験的糖尿病モデルの比較. 日 薬理誌 87, 105 112 (1986)

10）後藤正子, 井上 肇, 瀬山義幸, 山下三郎, 井上 治, 弓岡栄三郎 : 実験的糖尿病および実験的高脂血 症に対する漢方方剤 (大柴胡湯, 八味地黄丸, 白虎 加人参湯) の効果. 日薬理誌 93，179～186 (1989)

11) Van, Heyningen, R.: Formation of polyols by the lens of the rat with 'Sugar' cataract. Nature 184, 194 $\sim 195$ (1959)

12) Gabbay, K.H., Merola, L.O. and Field, R.A.: Sorbitol pathway: presence in nerve and cord with substrate accumulation in diabetes. Science 151, 209 210 (1966)

13）谷本 剛：アルドース還元酵素阻害剤一糖尿病性合 併症の予防と治療をめざして一．ファルマシア 24 , 459 463 (1988)

14）堀田 铣, 坂本信夫：ポリオール代謝異常とアル ドースリダクターゼ阻害剤。医学のあゆみ 156, 1003 1007 (1991)

15）長谷川和雄, 三国直二, 酒井 豊 : 実験的末梢神経 麻痺に対するビタミンB群の効果について。 日薬 理誌 74, 721 734 (1978)

16）杉浦 衛, 平野和行：新発色系を利用した Glucose oxidase-Peroxidase による血糖測定について。臨床 病理 23, 98 (1975)

17) Hayman, S. and Kinoshita, J.H.: Isolation and properties of lens aldose reductase. J. Biol. Chem. 240, 877 882 (1965)

18) Terashima, H., Hama, K., Yamamoto, R., Tsuboshima, M., Kikkawa, R., Hatanaka, I. and Shigeta, Y.: Effects of a new aldose reductase inhibitor on various tissues in vitro. J. Pharmacol. Exp. Ther. 229, 226 230 (1984)

19）山原條二, 壬生寛之, 沢田徳之助, 藤村 一, 滝野 晋吾, 吉川雅之, 北川 勲: 生薬の生物活性成分に 関する研究 Streptozotocin による病態モデルを用 いた山荣英抗糖尿病活性成分の検討. 薬誌 101, 86 $\sim 90$ (1981)

20）森下信一, 齋藤 隆, 庄司政満, 平井康晴, 田中 陽 : 牛黄, 人参製剤, 霊黄参の薬理作用. 日薬理誌 91, 129 140 (1988)

21）中薬大辞典：上海科学技術出版社 小学館編, 第 1 巻, p.642 643 (1985)

22) 中薬大辞典：上海科学技術出版社 小学館編, 第 4 巻, p.2314 2318 (1985)

23）中薬大辞典：上海科学技術出版社 小学館編, 第 $\mathbf{2}$ 巻, p. $827 \sim 830$ (1985)

24）鹿野昌彦, 沖 良隆, 青木孝彦: 牛車腎気丸の糖尿 病患者における血管拡張能 $\left(\mathrm{PGE}_{1}\right.$ との比較)。和 漢医薬会誌 7, 442～443 (1990)

25) Yasuda, H., Sonobe, M., Yamashita, M., Terada, M., Hatanaka, I., Huitian, Z. and Shigeta, Y.: Effect of prostaglandin $\mathrm{E}_{1}$ analogue TFC 612 on diabetic neuropathy in streptozocin-induced diabetic rats. Diabetes 38, 832 838 (1989)

26）会田 薫, 新藤英夫, 多和田真人, 女屋敏正 : 漢方 薬のラットレンズ aldose reductase 㧍よびヒト赤血 球中 sorbitol 蓄積に対する影響. ホルモンと臨床 33, 1163 1167 (1985) 
Abstract-Pharmacological effects of Gosha-jinki-gan-ryo extract: Effects on experimental diabetes. Masamichi SHOJI, Hitomi SATO, Yasuharu HIRAI, Yasuhiro OGUNI, Chishio SUGIMOTO, Shin-ichi MORISHITA and Chihiro ITO (Research Laboratories, Kyushin Pharmaceutical Co., Ltd., 1-31-7 Wada, Suginami-ku, Tokyo 166, Japan). Folia pharmacol. japon. 99, 143 152 (1992)

Pharmacological effects of Gosha-jinki-gan-ryo extract (KJE) on experimental diabetes induced by cyproheptadine $(\mathrm{CPH})$, aldose reductase activity, and experimental peripheral neuropathy were studied. The effects of KJE were compared with those of Hachimi-jio-gan-ryo extract (HJE). KJE at 417 $\mathrm{mg} / \mathrm{kg} /$ day (5 times the daily dose in humans) and $\mathrm{HJE}$ at $367 \mathrm{mg} / \mathrm{kg} /$ day ( 5 times the daily dose in humans) significantly inhibited the decrease in glucose tolerance by $\mathrm{CPH}$. KJE and HJE inhibited aldose reductase activity, when DL-glyceraldehyde was used as substrate, with IC50 values of $2.68 \times$ $10^{-5} \mathrm{~g} / \mathrm{ml}$ and $4.45 \times 10^{-5} \mathrm{~g} / \mathrm{ml}$, respectively and when D-glucose was used as substrate, with IC50 values of $1.04 \times 10^{-4} \mathrm{~g} / \mathrm{ml}$ and $1.55 \times 10^{-4} \mathrm{~g} / \mathrm{ml}$, respectively. $\mathrm{KJE}$ at $209 \mathrm{mg} / \mathrm{kg} /$ day $(2.5$ times the daily dose in humans) and $\mathrm{HJE}$ at $367 \mathrm{mg} / \mathrm{kg} /$ day significantly reduced peripheral neuropathy induced by crushing the sciatic nerve in rats. The potency of these effects of KJE was stronger than that of $\mathrm{HJE}$, when a comparison was made on the basis of the daily dose. 